\title{
EVALUASI KINERJA GURU PASCA KEGIATAN KELOMPOK KERJA GURU
}

\author{
Annura Wulan Darini Subandriyo \\ Email: nurawuandarini@yahoo.com \\ Program Studi Manajemen Pendidikan, Program Pascasarjana \\ Universitas Negeri Surabaya, Jalan Ketintang Baru XII No. 34 Surabaya
}

\begin{abstract}
This study aimed to evaluate teacher performance post activities Teachers Working Group in order to determine how optimal the result of teacher performance in implementing the tasks to create a syllabus, lesson plan, and the use of information and communication technology. This study used a qualitative approach to the type of evaluation research. Collecting data using the method of observation, interviews, and documentation. The data analysis technique is the reduction of data, coding categories, make notes refklesi, as well as presenting further disaggregation of data, checking data, and draw conclusions. The field data show overall teachers in groups of two and have followed Teachers Working Group able to create a syllabus. Teachers who have attended Teachers Working Group able to prepare lesson plans properly and in accordance with the theory of the preparation of lesson plans, so that the evaluation obtained is teachers have been able to prepare lesson plans. There need be no improvement, but needs to be improved in phase able to develop the lesson plan.
\end{abstract}

Keywords: evaluation of teacher performance, teacher working group

\begin{abstract}
Abstrak: Penelitian ini bertujuan untuk mengevaluasi kinerja guru pasca kegiatan Kelompok Kerja Guru (KKG) dalam rangka mengetahui seberapa optimal hasil kinerja guru dalam melaksanakan tugas menyusun silabus, rencana pelaksanaan pembelajaran (RPP), dan penggunaan teknologi informasi dan komunikasi (TIK). Penelitian ini menggunakan pendekatan kualitatif dengan jenis penelitian evaluasi. Pengumpulan data menggunakan metode observasi, wawancara, dan studi dokumentasi. Teknik analisis data adalah reduksi data, pengkodean kategori, membuat catatan refklesi, serta pemilahan data selanjutnya menyajikan data, melakukan pengecekan data, dan menarik kesimpulan. Data lapangan menunjukkan secara keseluruhan guru yang berada di gugus dua dan telah mengikuti KKG mampu menyusun silabus. Guru yang telah mengikuti KKG mampu menyusun RPP dengan baik dan sesuai dengan teori penyusunan RPP, sehingga evaluasi yang diperoleh adalah guru telah mampu menyusun RPP. Tidak perlu ada perbaikan, namun perlu ditingkatkan dalam fase mampu mengembangkan RPP.
\end{abstract}

Kata kunci : evaluasi kinerja guru, kelompok kerja guru

Setiap lembaga memiliki tujuan untuk lebih maju dan berkembang dari waktu ke waktu. Perkembangan lembaga dipengaruhi oleh kualitas pemangku tugas masing-masing lini. Salah satunya adalah kinerja pegawai. Lembaga pendidikan merupakan lembaga yang paling dekat dengan masyarakat. Melalui lembaga pendidikan, masyarakat bisa ikut serta berpartisipasi memajukan lembaga pendidikan. Sekolah merupakan lembaga pendidikan yang banyak mengikutsertakan masyarakat untuk memajukan sekolah melalui komite sekolah.
Selain masyarakat, guru merupakan salah satu senjata paling penting demi majunya sekolah dengan didukung oleh peran kepala sekolah yang memiliki kemampuan manajerial yang mumpuni. Lembaga pendidikan akan bisa dikatakan sebagai sekolah yang produktif apabila pemakaian sumber daya manusia (SDM), sumber daya alam (SDA), sumber daya budaya, serta proses pembelajaran berlangsung secara efektif dan efisien untuk mencapai tujuan yang sudah direncanakan (Pidarta, 2009). 
Guru sangat menentukan keberhasilan peserta didik, terutama dalam kaitannya dengan proses belajar mengajar. SDM yang dimaksud dalam dunia pendidikan adalah pengelola lembaga, pendidik, pegawai tata usaha, perwakilan peserta didik, dan komite sekolah (Pidarta, 2009). SDM tersebut sangat mendukung proses pembelajaran khususnya adalah pendidik. Komponen pendidikan yang paling menentukan dalam sistem pendidikan secara keseluruhan, yang harus mendapat perhatian sentral, pertama, dan utama adalah guru. Sosok guru akan senantiasa dikaitkan dengan segala sesuatu tentang pendidikan, karena guru adalah fokus utama sekaligus penentu baik buruknya hasil belajar dalam dunia pendidikan. Guru memegang peran utama dalam pembangunan pendidikan, khususnya yang diselenggarakan secara formal disekolah. Guru merupakan komponen yang paling berpengaruh terhadap terciptanya proses dan hasil pendidikan yang berkualitas. Oleh karena itu, upaya perbaikan apapun yang dilakukan untuk meningkatkan kualitas pendidikan, tidak akan memberikan sumbangan yang signifikan didukung oleh guru yang profesional dan berkualitas. Perbaikan kualitas pendidikan harus berpangkal dari guru dan berujung pada guru pula.

Undang-undang Nomor 14 Tahun 2005 tentang Guru dan Dosen pasal 1 menjelaskan bahwa guru adalah pendidik profesional dengan tugas utama mendidik, pembelajaran, membimbing; dan pasal 8 dijelaskan juga bahwa guru wajib memiliki kualifikasi akademik, kompetensi, sertifikat pendidik, sehat jasmani dan rohani, serta memiliki kemampuan untuk mewujudkan tujuan pendidikan nasional. Banyak cara yang dilakukan lembaga demi terciptanya kinerja guru yang baik. Tidak hanya lembaga sendiri yang melakukan upaya-upaya terbaik demi tercapainya tujuan guru memiliki kemampuan yang professional, pemerintah pun memberikan stimulus-stimulus yang beragam untuk meningkatkan kompetensi dan kinerja guru.

Pendidikan memiliki arti yang sangat penting bagi pertumbuhan bangsa Indonesia. Pembukaan Undang-undang Dasar 1945 alinea ke-4 menyatakan kemudian daripada itu untuk membentuk pemerintahan negara Indonesia yang melindungi segenap bangsa Indonesia dan seluruh tumpah darah Indonesia dan untuk memajukan kesejarteraan umum, mencerdaskan kehidupan bangsa. Kalimat yang perlu diperhatikan adalah pada bagian mencerdaskan kehidupan bangsa. Undang-undang Dasar 1945 pasal 5 mengamanatkan juga bahwa setiap warga negara mempunyai hak yang sama untuk memperoleh pendidikan yang bermutu; dan pasal 11 menegaskan bahwa pemerintah dan pemerintah daerah wajib memberikan layanan dan kemudahan, serta menjamin terselenggaranya pendidikan yang bermutu bagi setiap warga negara tanpa deskriminasi.

Rendahnya mutu pendidikan nasional, telah berpengaruh secara langsung maupun tidak langsung terhadap rendahnya mutu dan daya saing SDM Indonesia pada bursa tenaga kerja global. Fungsi, tujuan, dan kewajiban pemerintah untuk mewujudkan pendidikan yang bermutu bagi bangsa Indonesia telah dilakukan dari waktu ke waktu. Namun pengalaman empirik menunjukkan bahwa pembangunan mutu pendidikan nasional masih sangat memperihatinkan. Berdasarkan hasil penelitian United Nation Development Programe (UNDP) tahun 2007 tentang Indeks Pengembangan Manusia menyatakan Indonesia berada pada peringkat ke-107 dari 177 negara (Lailatussaadah, 2015). Indonesia memperoleh indeks 0,728 . Jika dibandingkan dengan negara ASEAN yang dilibatkan dalam penelitian, Indonesia berada pada peringkat ke-7 dari sembilan negara ASEAN. Salah satu unsur utama dalam penentuan komposit Indeks Pengembangan Manusia ialah tingkat pengetahuan bangsa atau pendidikan bangsa. Peringkat Indonesia yang rendah dalam kualitas sumber daya manusia ini adalah gambaran mutu pendidikan Indonesia yang masih sangat rendah.

Dellasera (2013) mengungkapkan bahwa Indonesia berada di peringkat ke-64 dari 120 berdasarkan penilaian Education Development Index (EDI). Total nilai EDI itu diperoleh dari rangkuman perolehan empat kategori penilaian, yaitu: (1) angka partisipasi pendidikan dasar; (2) angka melek huruf pada usia 15 tahun ke atas; (3) angka partisipasi menurut kesetaraan gender; dan (4) angka bertahan siswa hingga Kelas V sekolah dasar (Unesco, 2013). Sementara itu UNDP (2011) juga telah melaporkan Human 
Development Index (HDI) Indonesia mengalami penurunan dari peringkat 108 pada 2010 menjadi peringkat 124 pada tahun 2012 dari 180 negara, dan pada Maret 2013 dilaporkan naik tiga peringkat menjadi urutan ke-121 dari 185 negara. Data ini meliputi aspek tenaga kerja, kesehatan, dan pendidikan. Dilihat dari kisaran peringkatnya, memang menunjukkan kenaikan, tetapi jika dilihat dari jumlah negara partisipan, hasilnya tetap saja Indonesia tidak naik peringkat.

Berkaitan dengan hal tersebut, Direktorat Jenderal Peningkatan Mutu pendidik dan Tenaga kependidikan (Ditjen PMPTK) Depdiknas, melalui Lembaga Penjaminan Mutu Pendidikan (LPMP) selalu berupaya untuk meningkatkan mutu pendidikan nasional melalui sektor guru. Salah satu upaya tersebut yaitu memberdayakan Kelompok Kerja Guru (KKG) pada jenjang sekolah dasar (SD) dan musyawarah guru mata pelajaran (MGMP) pada jenjang sekolah menengah pertama (SMP) dan sekolah menengah atas (SMA), dengan penyaluran dana blockgrant. KKG dan MGMP dapat menjadi sarana peningkatan mutu guru terutama dalam peningkatan kompetensinya dan mutu pembelajaran yang diampu. Dalam kaitannya dengan peningkatan kompetensi guru, kegiatan utama KKG dan MGMP adalah mendorong pencapaian empat kompetensi guru sesuai dengan amanat Undang-undang Nomor 14 Tahun 2005 tentang Guru dan Dosen. Program kerja KKG dan MGMP dalam konteks itu perlu difokuskan pada upaya peningkatan dan pengembangan kompetensi pedagogik, kompetensi kepribadian, kompetensi sosial, dan kompetensi profesional.

Undang-undang Nomor 14 Tahun 2005 tentang Guru dan Dosen pasal 1 ayat 4 menjelaskan profesional adalah pekerjaan atau kegiatan yang dilakukan oleh seseorang dan menjadi sumber penghasilan kehidupan yang memerlukan keahlian, kemahiran, atau kecakapan yang memenuhi standar mutu atau norma tertentu serta memerlukan pendidikan profesi. Berbagai usaha peningkatan mutu salah satunya adalah melaluipeningkatan sumber daya manusiapengelola pendidikan. Sebagai upaya meningkatkan mutu pendidikan, khususnya di SD, usaha nyata yang dilakukan antara lain ialah dengan dikeluarkannya Surat Keputusan Direktorat Jenderal Pendidikan Dasar dan
Menengah Nomor 079/C/Kep/I/1993 tentang Pedoman Pelaksanaan Sistem Pembinaan Profesi (SPP) Guru melalui Kelompok Kerja Guru SD (KKG), dan Kelompok Kerja Kepala Sekolah SD (KKKS), dan Kelompok Kerja Pengawas Sekolah TK/SD (KKPS); yang menyatakan pembentukan wadah KKG dan Sistem Pembinaan Profesional (SPP) guru dan tenaga kependidikan lainnya dalam kerangka peningkatan mutu tenaga kependidikan dan peningkatan mutu proses belajar pembelajaran. Peraturan Pemerintah Nomor 19 Tahun 2005 tentang Standar Nasional Pendidikan pasal 6 ayat 1 menyebutkan bahwa kurikulum untuk jenis pendidikan umum, kejuruan, dan khusus pada jenjang pendidikan dasar dan menengah pada butir (e) menyatakan tentang kelompok mata pelajaran jasmani, olahraga, dan kesehatan.

Kelompok mata pelajaran jasmani, olahraga, dan kesehatan dimaksud untuk mendorong pertumbuhan fisik, perkembangan psikis, keterampilan motorik, pengetahuan, dan penalaran. Penghayatan nilai-nilai (sikap mental, emosional, sportivitas, spiritual, sosial) serta pembiasaan pola hidup sehat yang bermuara untuk merangsang pertumbuhan dan perkembangan kualitas fisik dan psikis yang seimbang untuk hal tersebut diatas maka perlu adanya organisasi profesi. Undang-undang Nomor 14 Tahun 2005 tentang Guru dan Dosen pasal 41 dan 42 menjelaskan tentang organisasi profesi berfungsi untuk memajukan profesi, meningkatkan kompetensi, karier, wawasan kependidikan, perlindungan profesi, kesejahteraan, dan pengabdian kepada masyarakat. Hal ini menjadi sebuah usaha peningkatan mutu guru yang istimewa karena program KKG hanya diperuntukkan bagi guru pada jenjang SD. KKG berkedudukan sebagai lembaga, organisasi atau wadah pengembangan profesionalisme guru.

Peraturan Pemerintah Nomor 74 Tahun 2008 tentang Guru pasal 1 ayat 13 menyatakan bahwa pendidikan dasar adalah jenjang pendidikan pada jalur pendidikan formal yang melandasi jenjang pendidikan menengah yang diselenggarakan pada satuan pendidikan yang berbentuk Sekolah Dasar (SD) dan Madrasah Ibtidaiyah (MI) atau bentuk lain yang sederajat serta menjadi satu kesatuan kelanjutan pendidikan pada satuan pendidikan yang berbentuk Sekolah Menengah 
Pertama (SMP) dan Madrasah Tsanawiyah (MTs) atau bentuk lain yang sederajat. SD merupakan jenjang pendidikan yang merupakan pijakan dasar psikologi perkembangan anak. Oleh sebab itu, kemampuan guru dianggap sebagai suatu sarana penting bagi keberhasilan pendidikan. Suatu hal yang unik adalah jenjang SD merupakan jenjang yang sangat menantang bagi setiap tenaga pengajar, karena dari pendidikan dasar inilah penentu keberlangsungan perkembangan siswa pada jenjang berikutnya.

Anak-anak yang berada dalam jenjang SD merupakan anak dengan katagori banyak mengalami perubahan yang sangat drastis, baik mental maupun fisik. Selain mengalami perubahan yang pesat, pada usia SD anak memerlukan lingkungan baru yang lebih luas seperti sekolahan (Kartono, 1990). Karakteristik anak usia SD adalah senang bermain, senang bergerak, senang bekerjadalam kelompok, serta senang merasakan atau melakukan sesuatu secara langsung. Anak sekolah dasar (SD) mulai mengalami perubahan dalam cara pandang dari subjektif ke objektif (Kartono, 1990). Cara pandang objektif ini mengakibatkan mereka ketika melihat semua kejadian ingin diselidiki dengan tekun dan penuh minat. Untuk memenuhi kebutuhan peserta didik dengan kondisi perubahan psikologis dan fisik yang sangat drastis, maka guru pada jenjang sekolah dasar dituntut untuk memahami dan diharapkan memiliki pemahaman yang lebih baik dalam menentukan proses pembelajaran ataupun perlakuan pada peserta didik sesuai dengan karakteristiknya.

Peningkatan pendidikan khususnya di SD menjadi fokus perhatian utama dalam rangka meningkatkan kualitas SDM. Hal ini dikarenakan SD merupakan jenjang pendidikan formal pertama yang mempunyai serta mengemban tanggung jawab untuk mengembangkan sikap dan kemampuan serta memberikan pengetahuan dan keterampilan dasar pada peserta didik. Pengembangan pendidik, khususnya pengembangan profesional guru melalui pelatihan kompetensi berkelanjutan yang diwadahi oleh program KKG, merupakan usaha mempersiapkan guru agar memiliki berbagai wawasan, pengetahuan, keterampilan, dan memberikan rasa percaya diri untuk melaksanakan tugas dan kewajibannya sebagai petugas profesional.
Pengembangan atau peningkatan kemampuan profesional harus bertolak pada kebutuhan atau permasalahan nyata yang dihadapi oleh guru.

Semakin lama jaman semakin maju dan berkembang, sehingga menuntut manusia minimal sama bahkan melebihi dari kondisi jaman pada masanya. Tuntutan di dunia pendidikan pada khususnya memiliki peran penting untuk memajukan masyarakat. Melalui guru peserta didik akan diajarkan segala sesuatunya secara baik. Hasil dari siswa yang dididik secara baik tentunya melalui guru yang kompeten dalam proses pembelajaran. Kemampuan guru yang dituntut untuk bisa mengajar dengan baik inilah yang membuat pemerintah mengadakan pembinaan melalui KKG. Berhasilkah KKG menjadi wadah guru untuk maju? Hal ini menjadi sangat penting untuk diteliti melalui evaluasi kinerja guru pasca mengikuti KKG. Hasil evaluasi kinerja guru memang dihasilkan melalui banyak faktor, salah satunya akan terlihat tentang peran wadah KKG yang baik ataupun kurang baik.

\section{METODE}

Pelaksanaan penelitian ini adalah mengevaluasi kinerja guru pasca mengikuti pelatihan KKG. Dalam mengevaluasi kinerja guru tersebut, maka peneliti menggunakan pendekatan kualitatif. Pendekatan ini bermaksud memahami fenomena yang dialami oleh subjek penelitian dengan cara deskripsi melalui katakata dan bahasa, pada suatu konsep khusus yang alamiah dengan memanfaatkan berbagai metode yang ilmiah. Terkait dengan penelitian kualitatif yang memahami fenomena secara menyeluruh, maka data yang terhimpun merupakan data yang bisa dideskripsikan melalui kata-kata dan bahasa oleh karena itu, pendekatan kualitatif dalam penelitian ini bersifat deskriptif.

Penelitian ini termasuk dalam jenis penelitian evaluasi. Secara umum, penelitian evaluasi yang dilakukan oleh peneliti merupakan penelitian yang dilaksanakan dengan tujuan mengumpulkan data tentang apakah subjek penelitian telah mengimplementasikan kinerjanya sesuai dengan kebijakan. Setelah melakukan evaluasi terhadap subjek, maka data tersebut dapat digunakan untuk memperbaiki bagian-bagian yang lemah dengan tujuan meningkatkan mutu pendidikan. Desain 
penelitian evaluatif dilakukan dengan tahap: (1) survei awal; (2) pengevaluasian dibandingkan dengan standar atau teori; dan (3) perbaikan bagi. Tahap survei lapangan pada penelitian ini dilakukan untuk melihat kegiatan KKG yang difokuskan pada materi apa saja yang diajarkan.

Seteleh itu survei dilakukan mula-mula pada satu sekolah peserta KKG Gugus 2. Proses survei di salah satu sekolah tersebut menunjukkan adanya bermacam-macam kondisi kinerja guru terkait dampak KKG. Kondisi kinerja guru selama masih mengikuti KKG menunjukkan masih adanya guru yang belum lancar melakukan hal-hal terkait materi KKG dan adapula yang sudah fasih di beberapa indikator materi yang diajarkan dalam KKG. Tahap ini lah yang menjadi dasar peneliti untuk mengevaliasi secara mendalam mengenai apakah pelaksanaan materi KKG melalui kinerja guru yang dilaksanakan peserta sudah sesuai dengan standar atau belum.

Evaluasi ini dilaksanakan pada seluruh peserta KKG Gugus 2. Jika ditemukan adanya kesenjangan pada kinerja guru pasca KKG dengan teori atau standar yang sudah ada, maka peneliti akan memberikan saran atau rekomendasi yang disusun guna perbaikan kinerja guru yang lebih baik. Penelitian ini dilakukan di tujuh titik SD yang menjadi subjek utama penelitian, di mana di sekolah-sekolah tersebut terdapat perwakilan guru yang menjadi peserta KKG Gugus 2 Kecamatan Sedati Kabupaten Sidoarjo. Sekolah tersebut adalah: (1) SD Negeri Pabean I; (2) SD Negeri Pabean II; (3) SD Negeri Sedati Gede I; (4) SD Negeri Sedati Agung; (5) SD Negeri Pranti; (6) SD Negeri Semampir; dan (7) SD Negeri Betro.

\section{HASIL}

Pembinaan guru SD melalui program KKG merupakan salah satu wujud usaha pemerintah serta guru-guru untuk meningkatkan kemampuan atau kinerja guru dalam proses pembelajaran peserta didik sekolah dasar yang jika dilihat dari segi perkembangan fisik dan mental mengalami perubahan yang kompleks. Namun, apakah setelah melakukan pembinaan pada program KKG kinerja tenaga pendidik yang bersangkutan berhasil ataupun malah gagal dalam menerapkan kompetensi-kompetensi yang telah diajarkan dalam forum KKG. Berikut ini akan diuraikan temuan penelitian pada tujuh lokasi penelitian.

\section{SD Negeri Pabean I}

Mengevaluasi kinerja guru dalam penyusunan silabus guru yang telah mengikuti KKG yaitu kinerja guru dalam menyusun silabus telah dilaksanakan dengan baik pasca KKG. Tidak perlu ada perbaikan, namun perlu ditingkatkan untuk lebih bisa mengembangkan kemampuan guru dalam menyusun silabus. Mengevaluasi kinerja guru dalam penyusunan RPP guru yang telah mengikuti KKG. Guru telah menyusun RPP dengan baik pasca KKG, sehingga kinerja guru telah sesuai dengan teori kinerja guru. Tidak perlu ada perbaikan, namun perlu ditingkatkan dalam fase mampu mengembangkan RPP.

\section{SD Negeri Pabean II}

Mengevaluasi kinerja guru dalam penyusunan silabus guru yang telah mengikuti $\mathrm{KKG}$, kinerja guru dalam menyusun silabus telah dilakukan dengan baik pasca $\mathrm{KKG}$, namun pengakuan dari kepala sekolah dan guru memerlukan waktu untuk proses hingga guru benar-benar paham, sehingga proses perubahan sedikit lambat. Hasil evaluasi yang diperoleh adalah guru telah mampu menyusun silabus. Perlu ada perbaikan dalam hal pengadaan jadwal pelatihan intern secara rutin dari kepala sekolah untuk mengasah kemampuan guru. Mengevaluasi kinerja guru dalam penyusunan rpp guru yang telah mengikuti KKG. guru telah menyusun RPP dengan baik pasca KKG. Tidak perlu ada perbaikan, namun perlu ditingkatkan dalam fase mampu mengembangkan RPP. Namun demikian guru mengalami kesulitan untuk mengaplikasikan apa yang didapatkan dari KKG secara cepat, karena masalah waktu. Penyebab dari adanya faktor eksternal yang mempengaruji kinerja guru adalah kurangnya motivasi internal.

\section{SD Negeri Sedati Gede I}

Mengevaluasi kinerja guru dalam penyusunan silabus guru yang telah mengikuti KKG, hasil evaluasi menunjukkan bahwa guru telah menyusun silabus dengan 
baik pasca KKG. Tidak perlu ada perbaikan, namun perlu ditingkatkan dalam fase mampu mengembangkan silabus. Mengevaluasi kinerja guru dalam penyusunan RPP guru yang telah mengikuti KKG, hasil evaluasi menunjukkan bahwa guru telah menyusun RPP dengan baik pasca KKG. Tidak perlu ada perbaikan, namun perlu ditingkatkan dalam fase mampu mengembangkan RPP.

\section{SD Negeri Sedati Agung}

Mengevaluasikinerjaguru dalampenyusunan silabus guru yang telah mengikuti KKG, temuan data menunjukkan bahwa guru telah menyusun silabus dengan baik pasca KKG. Tidak perlu ada perbaikan, namun perlu ditingkatkan dalam fase mampu mengembangkan silabus. Mengevaluasi kinerja guru dalam penyusunan RPP guru yang telah mengikuti $\mathrm{KKG}$, temuan data menujukkan bahwa guru telah menyusun RPP dengan baik pasca KKG. Tidak perlu ada perbaikan, namun perlu ditingkatkan dalam fase mampu mengembangkan RPP.

\section{SD Negeri Pranti}

Mengevaluasi kinerjaguru dalam penyusunan silabus guru yang telah mengikuti KKG, kinerja guru dalam melaksanakan penyusunan silabus telah dilakukan dengan baik pasca KKG. Tidak perlu ada perbaikan, namun perlu ditingkatkan dalam fase mampu mengembangkan silabus. Mengevaluasi kinerja guru dalam penyusunan RPP guru yang telah mengikuti KKG, kinerja guru melaksanakan penyusunan RPP dengan baik pasca KKG. Tidak perlu ada perbaikan, namun perlu ditingkatkan dalam fase mampu mengembangkan RPP.

\section{SD Negeri Semampir}

Mengevaluasi kinerja guru dalam penyusunan silabus guru yang telah mengikuti $\mathrm{KKG}$, guru telah menyusun silabus dengan baik pasca KKG, sehingga kinerja guru telah sesuai dengan indikator kinerja guru dalam melaksanakan perencanaan pembelajaran. Tidak perlu ada perbaikan, namun perlu ditingkatkan dalam fase mampu mengembangkan silabus. Mengevaluasi kinerja guru dalam penyusunan RPP guru yang telah mengikuti KKG. Guru telah menyusun RPP dengan baik pasca KKG. Tidak perlu ada perbaikan, namun perlu ditingkatkan dalam fase mampu mengembangkan RPP.

\section{SD Negeri Betro}

Mengevaluasi kinerjaguru dalampenyusunan silabus guru yang telah mengikuti KKG, temuan data menunjukkan bahwa guru telah menyusun silabus dengan baik pasca KKG. Tidak perlu ada perbaikan, namun perlu ditingkatkan dalam fase mampu mengembangkan silabus. Mengevaluasi kinerja guru dalam penyusunan RPP guru yang telah mengikuti KKG, temuan data menunjukkan bahwa guru telah menyusun RPP dengan baik pasca KKG. Tidak perlu ada perbaikan, namun perlu ditingkatkan dalam fase mampu mengembangkan RPP.

\section{PEMBAHASAN}

\section{Mengevaluasi Penyusunan Silabus Guru}

Pelaksanaan penyusunan silabus guru yang telah mengikuti KKG Gugus 2 Kecamatan Sedati, hasil evaluasi yang diperoleh melalui penelitian pada tujuh sekolah. Pelaksanaan tahap penyusunan silabus, berdasarkan temuan penelitian di lapangan, pelaksanaan penyusunan silabus sudah lakukan oleh guru yang telah mengikuti KKG. Terbukti bahwa guru-guru telah melakukan perencanaan terkait penyusunan silabus dengan cara mengumpulkan berbagai macam referensi buku yang sesuai dengan materi pembelajaran guru tersebut. Kesesuaian materi yang dipilih oleh setiap sekolah merupakan salah satu ciri dari pengembangan silabus. Hal ini sesuai dengan pendapat Mulyasa (2010) bahwa setiap satuan pendidikan diberi kebebasan dan keleluasaan dalam mengembangkan silabus sesuai dengan kondisi dan kebutuhan masingmasing sekolah.

Setelah melakukan perencanaan guru melakukantahap pelaksanaan penyusunan silabus. Dalam hasil penelitian, memang ditemukan hasil yang bervariasi terkait penyusunan silabus. Ada guru yang menyusun silabus secara mandiri, ada juga guru yang menyusun silabus bersama tim KKG. Hal ini sesuai dengan yang diutarakan Depdiknas dalam sosialisasi pengembangan silabus bahwa penyusunan silabus bisa dilakukan secara mandiri atau dengan tim seperti KKG. Sama seperti yang dikemukakan oleh Depdiknas, 
Muslich (2008) menyebutkan bahwa yang mengembangkan dan menyusun silabus adalah guru kelas atau mata pelajaran, kelompok guru kelas atau mata pelajaran, $\mathrm{KKG}$, atau Dinas Pendidikan.

Penyusunan silabus yang dilakukan berkelompok melalui KKG atau MGMP dikembangkan sesuai dengan standar pengembangan silabus yang tertuang dalam Peraturan Pemerintah Nomor 19 Tahun 2005 tentang Standar Nasional Pendidikan pasal 17 ayat 2 yang menyatakan sekolah dan komite sekolah atau madrasah dan komite madrasah, mengembangkan kurikulum tingkat satuan pendidikan dan silabusnya berdasarkan kerangka dasar kurikulum dan standar kompetensi lulusan, di bawah supervisi dinas kabupaten/kota yang bertanggung jawab di bidang pendidikan untuk SD, SMP, SMA, dan SMK, dan departemen yang menangani urusan pemerintahan di bidang agama untuk MI, MTS, MA, dan MAK. Penyebab guru kurang optima dari faktor eksternal yang mempengaruhi kinerja guru adalah kurangnya motivasi internal. Faktor-faktor yang mempengaruhi kinerja menjadi tiga kelompok, yaitu faktor individual, faktor psikologis, dan faktor organisasi (Simamora, 1995).

Implikasi yang akan terjadi ketika guru tersebut tidak engan segera mengatasi masalah waktu, atau sekolah tidak segera memutuskan solusi agar guru yang bersangkutan dapat melaksanakan perubahan dengan cepat adalah: (1) murid akan mengalami ketertinggalan teknologi dan informasi dibandingkan sekolah lain; (2) guru akan semakin lama memupuk kegelisahan karena merasa minder dengan rekan kerjanya yang jauh lebih maju ketimbang dirinya. Ketika ada guru yang merasa kurang menemukan waktu luang untuk melakukan perubahan penting dalam tujuannya untuk menjadi guru yang lebih maju, kepala sekolah melakukan pembinaan intern guru-guru secara rutin di luar jam sekolah. Faktor yang mempengaruhi kinerja guru salah satunya adalah mengenai pemimpin (Mulyasa, 2007). Terdapat sepuluh faktor yang dapat meningkatkan kinerja guru, baik faktor internal maupun eksternal, yaitu: (1) dorongan untuk bekerja; (2) tanggung jawab terhadap tugas; (3) minat terhadap tugas; (4) penghargaan terhadap tugas; (5) peluang untuk berkembang; (6) perhatian dari kepala sekolah; (7) hubungan interpersonal dengan sesama guru; (8) kelompok diskusi terbimbing; dan (9) layanan perpustakaan (Mulyasa, 2007).

\section{Mengevaluasi Penyusunan Rencana Pelaksanaan Pembelajaran Guru}

Hasil penelitian yang diperoleh, guru yang telah mengikuti KKG paham betul mengenai tahapan penyusunan RPP walaupun memang tidak hafal, sehingga masih perlu melihat pedoman tahapan penyusunan RPP. Tahapan yang dipahami oleh guru peserta KKG dimulai dari mencantumkan identitas nama sekolah, mata pelajaran, kelas atau semester, standar kompetensi, kompetensi dasar, indikator, alokasi waktu. Setelah itu mencantumkan semua komponen RPP seperti materi pembelajaran dan metode. Tahapan penyusunan RPP guru ini telah sesuai dengan pedoman penyusunan RPP yang diberikan saat KKG berlangsung. Tahap penyusunan RPP dimulai dari mencantumkan identitas RPP, tujuan pembelajaran, materi pembelajaran, metode pembelajaran, langkahlangkah kegiatan pembelajaran, sumber belajar, dan penilaian (Jingga, 2013).

Hasil penelitian terkait penyusunan komponen RPP guru menunjukkan bahwa guru yang telah mengikuti KKG mampu menyusun komponen RPP dengan baik, walaupun masih ada sedikit kekurangan dalam proses pengembangan bahan ajar, baik dalam penggunaan TIK atau tujuan untuk menjadikan pembelajaran aktif, kreatif, dan inovatif. Hasil RPP yang dibuat guru, mereka telah mencantumkan komponen RPP mulai dari identitas mata pelajaran, standar kompetensi,kompetensi dasar, indikator, tujuan pembelajaran, materi ajar, alokasi waktu, metode pembelajaran, kegiatan pembelajaran, penilaian hasil belajar, sumber belajar. Hal ini sesuai dengan penyusunan RPP yang diambil dari Peraturan Menteri Pendidikan Nasional Nomor 41 tahun 2007 tentang Standar Proses. Komponen-komponen yang harus dipahami guru dalam pengembangan RPP, antara lain kompetensi dasar, materi standar, hasil belajar, indikator hasil belajar, penilaian, dan prosedur pembelajaran (Mulyasa, 2010).

Pelaksanaan pinsip penyusunan RPP, guru yang telah mengikuti KKG dalam penelitian ini telah menerapkan prinsip penyusunan RPP sesuai dengan Peraturan Menteri Pendidikan Nasional 
Nomor 41 Tahun 2007 tentang Standar Proses, sehingga keadaan ini minimal dipertahankan dengan harapan guru yang bersangkutan bisa mengembangkan kemampuanya dalam menyusun RPP. Adapun prinsip penyusunan RPP yang diimplementasikan guru sesuai dengan Peraturan Menteri Pendidikan Nasional Nomor 41 Tahun 2007 tentang Standar Proses adalah memperhatikan perbedaan individu peserta didik, mendorong partisipasi aktif peserta didik, mengembangkan budaya membaca dan menulis, memberikan umpan balik dan tindak lanjut, keterkaitan dan keterpaduan, menerapkan teknologi informasi dan komunikasi. Terkait prinsip memperhatikan perbedaan individu, Mulyasa (2010) mengungkapkan bahwa pengembangan RPP harus memperhatikan karakteristik peserta didik terhadap materi standar yang dijadikan bahan kajian. Hasil evaluasi yang diperoleh peneliti dapat disimpulkan bahwa semua guru yang telah mengikuti KKG telah melaksanakan penyusunan silabus dan RPP sesuai dengan standar teori. Hal ini telah sesuai dengan apa yang dicita-citakan oleh KKG sebagai wadah meningkatkan kinerja guru.

\section{KESIMPULAN}

Penyusunan komponen silabus, berdasarkan temuan penelitian pada tujuh SD Negeri yang telah mengikuti KKG, menunjukkan dalam menyusun komponen silabus, baik standar kompetensi dan kompetensi dasar. Guru yang mengikuti KKG tidak mengalami kendala, sehingga tidak perlu dilakukan perbaikan. Jika disimpulkan, pemahaman mereka terkait tentang komponen silabus salah satunya mengenai standar kompetensi dan kompetensi dasar sudah merujuk pada Peraturan Menteri Pendidikan Nasional Nomor 22 tahun 2006 tentang Standar Isi untuk Satuan Pendidikan Dasar dan Menengah yang menyatakan bahwa standar kompetensi yakni ukuran kemampuan minimal yang mencakup pengetahuan, keterampilan dan sikap yang hars dicapai, diketahui, dan mahir dilakukan oleh peserta didik pada setiap tingkatan satuan materi yang diajarkan. Sedangkan kompetensi dasar adalah penjabaran standar kompetensi yang cakupan materinya lebih sempit dibanding dengan standar kompetensi.
Guru dalam penyusunan silabus guru yang telah mengikuti KKG komponen silabus yang terdapat dalam hasil penyusunan silabus sudah sesuai dengan komponen yang ditetapkan oleh Depdiknas. Pelaksanaan prinsip penyusunan silabus, berdasarkan temuan hasil penelitian pemahaman guru tentang tahapan penyusunan silabus menunjukkan bahwa dalam memahami tahap penyusunan silabus sudah baik, sehingga tidak perlu diadakan perbaikan namun tetap harus dilakukan pengamatan rutin baik melalui supervisi, pelatihan berkelanjutan ataupun pelatihan pengembangan silabus secara terbimbing supaya kemampuan yang dimiliki guru tidak mudah lupa bahkan bisa semakin meningkat. Pemahaman guru mengenai prinsip penyusunan silabus sudah cukup baik, mereka mempertimbangkan prinsip pengembangan silabus, yaitu ilmiah, relevan, sistematis, konsisten, memadai, aktual, kontekstual, fleksibel, dan menyeluruh.

\section{DAFTAR RUJUKAN}

Dellasera, Q. 2013. Kualitas Pendidikan Indonesia (Refleksi 2 Mei), (Online), (http://edukasi. kompasiana.com/2013/05/03/kualitaspendidikan-indonesia-refleksi-2-mei-552591. html), diakses 3 Februari 2014.

Jingga, G. M. 2013. Panduan Lengkap Menyusun Silabus dan Rencana Pelaksanaan Pembelajaran (Konsep dan Implementasi Disertai Contoh). Yogjakarta: Araska.

Kartono, K. 1990. Psikologi Anak (Psikologi Perkembangan). Bandung: Mandar Maju.

Lailatussaadah. 2015. Upaya Peningkatan Kinerja Guru. Intelektualita, 3(1): 15-25.

Mulyasa. E. 2007. Standar Kompetensi dan Sertifikasi Guru. Bandung: PT Remaja Rosdakarya.

Mulyasa, E. 2010. Kurikulum Tingkat Satuan Pendidikan. Bandung: PT Remaja Rosdakarya.

Muslich, M. 2008. KTSP Pembelajaran Berbasis Kompetensi dan Kontekstual. Jakarta: PT Bumi Aksara.

Peraturan Menteri Pendidikan Nasional Nomor 22 tahun 2006 tentang Standar Isi untuk Satuan Pendidikan Dasar dan Menengah, (Online), (http://kemdikbud.go.id), diakses 23 Mei 2016.

Peraturan Menteri Pendidikan Nasional Nomor 41 tahun 2007 tentang Standar Proses, (Online), (http://kemdikbud.go.id), diakses 23 Mei 2016. 
Peraturan Pemerintah Nomor 19 Tahun 2005 tentang Standar Nasional Pendidikan, (Online), (http:// indonesia.go.id), diakses 2 Juli 2016.

Peraturan Pemerintah Nomor 74 Tahun 2008 tentang Guru, (Online), (http://indonesia.go.id), diakses 2 Juli 2016.

Pidarta, M. 2009. Wawasan Pendidikan. Surabaya: SIC.

Simamora, H. 1995. Manajemen Sumber Daya Manusia. Yogyakarta: Bagian Penerbitan STIE YKPN.

Surat Keputusan Direktorat Jenderal Pendidikan Dasar dan Menengah Nomor 079/C/Kep/I/1993 tentang Pedoman Pelaksanaan Sistem Pembinaan Profesi (SPP) Guru melalui Kelompok Kerja Guru SD (KKG), dan Kelompok Kerja Kepala Sekolah SD (KKKS), dan Kelompok Kerja Pengawas Sekolah TK/SD (KKPS), (Online), (http://kemdikbud.go.id), diakses 23 Mei 2016.
Undang-undang Dasar 1945, (Online), (http:// indonesia.go.id), diakses 2 Juli 2016.

Undang-undang Nomor 14 Tahun 2005 tentang Guru dan Dosen. 2006. Bandung: Citra Umbara.

Unesco. 2013. The Sector for External Relations and Public Information. Paris: Unesco.

United Nation Development Programe. 2011. Human Development Report 2011 - Sustainability and Equity: A Better Future for All. New York: UNDP. 